\title{
The Problem And Its Impacts Of Mangrove Rehabilitation In Karangsong
}

\author{
Fatimatuzzahroh Feti $^{1}$, Hadi Sudharto $\mathrm{P}^{2}$ \\ ${ }^{1}$ Doctorate Program of Environmental Studies, School of Postgraduate Studies, Diponegoro University, Semarang - Indonesia \\ ${ }^{2}$ Study Program of Environmental Studies, School of Postgraduate Studies, Diponegoro University, Semarang - Indonesia
}

\begin{abstract}
Efforts to conserve coastal abrasion areas due to the overlapping of coastal development that causing in the overcapacity of environmental carrying capacity can be done among others by rehabilitating mangroves. Community development is an approach to help society by analyzing their problems and finding their solutions. Some studies show that mangrove rehabilitation be successful with a community development approach. However there is a new problem when the success of mangrove rehabilitation in Karangsong began to be claimed by one of the parties from several stakeholders who involved in mangrove rehabilitation activities. Beside that, problems arise from local governments claiming ownership of mangrove rehabilitation areas. The transfer of ownership is feared to threaten the sustainability of the mangrove forest area because the mangrove forest area is also an ecotourism, should be damaged conservation areas because it only focuses only on ecotourism. This paper reviews how the impact of onesided claiming of one of the stakeholders and also the transfer of ownership of mangrove conservation area. To achieve the sustainability of the mangrove conservation area is needed regulation that not only benefits the government but also must involve the community in making the policy. In addition to the importance of sustainability of mangrove conservation is the main thing in conservation efforts.
\end{abstract}

Keywords: mangrove-rehabilitation; coastal-abrasion; community development

\section{Introduction}

Mangrove rehabilitation have a big impact that can reduce climate change. As a highly productive stroring carbon in soil and dead rotes, mangrove have rates equivalent to tropical forest [1]. Community effort to rehabilitate mangrove is a real action in creating public awareness of climate change, also as a form of participation to make a low carbon society. As we know that mangroves have ability to storing carbon belowground, and have higher carbon mass ratios than terrestrial trees. That makes mangrove have a great value as a saving carbon to reduce the impact of global warming [1].

Mangrove forest is a coastal vegetation community of tropical forests that is dominated by several species of mangrove trees that are able to grow and develop in tidal areas of muddy beaches [2]. Climate Change Mitigation and Adaptation (CCMA) stated that mangrove provide significant contribution to human well-being with high carbon sequestration and coastal protection [3]. Aside from being a barrier to abrasion and carbon sinks, mangrove forests are also often developed into ecotourism.

Increasing number of mangrove rehabilitation program are undertaken to point out ecosystem services

\footnotetext{
* Corresponding author: feti.faza@gmail.com
}

for community based conservation [4]. Conservation and coastal protection are important goals of rehabilitation. Rehabilitation hammered at modifying ecosystem structural or functional characteristics reduce ecosystem damage [4]. Tree and structural diversity usually not considering in early mangrove rehabilitation program and however focused to establish forest cover and coastal protection [4].

At first, mangrove rehabilitation in Karangsong aims to withstand abrasion which threatens the lives of the surrounding community. Mangrove planting began in 2007 until 2015 the Mangrove forest area is inaugurated as a mangrove center for the West Java region by the Indonesian Ministry of Environment. The opening of mangrove areas as ecotourism then raises several problems. The mangrove forest area which was originally intended as an edupark area, turn into tourism area will also affect its management. In addition, the Decree of the Indramayu District Head stating that ownership of mangrove forest land has shifted to the government has also led to a new polemic. This raises a number of concern, including the transfer of ownership that causing conflicts between local groups and local governments. Based on that problem, mangrove management as a conservation area will be abandoned and it can threaten 
the sustainability of mangrove forest as conservation areas.

\section{Literatur Review}

Some research has been done related to the mangrove rehabilitation. Prayudha et al, (2014) mentions that the lack information and scientific studies would make local groups conservationist mangrove does not have sufficient references to make a programs or management policy in developing mangrove rehabilitation activities [5]. Prayudha (2014) also argued that the local grup must coordinate with community leaders and local government, so that local grup can increased comparative studies and conducted consultations and guidance from an expert [5].

Wahyuni et al (2015) suggested that ecotourism development strategies can be carried out with; develop mangrove conservation and rehabilitation as a subdivision of tourism programs, increasing community participation and community development, strenghtened law enforcement and official regulation to preserve mangroves, and strengthen the concept of ecotourism [6]. Kustanti et al (2014) studied Transfer of ownership of mangrove forests covering 700 ha to Lampung University from East Lampung Regency has changed subsequent ownership rights with three types of ownership, namely 1) the right to enter and utilize; 2) the right to manage; and 3) the right to issue unauthorized persons [7].

Kustanti et al., (2014) also showed that actor interest be able to occur conflict of interest between stakeholder and threaten mangrove forest management sustainability. As a Common Pool Resources (CPRs), mangrove forests in protected area meet difficulties to define in a regulation of granting ownership rights. Same powerful interest among stakeholder bringing on appearance of potential conflict and need to discuss to set rules between stakeholder [8]. University of Lampung as one of stakeholder need to enhance community household in education mangrove forest biodiversity in term of sustainability mangrove ecosystem services. Beside that regulation from government need in order to protect mangrove forests [7].

The results of Gunawan's et al., research, (2018) show that there has been a change in land ownership status in the mangrove area. The Pantai Lestari Group, which is supported by the Karangsong, Diskanla and Pertamina village governments, is key actors in mangrove rehabilitation activities [9]. Coordination and synergy of stakeholders, as well as empowerment of local communities need to be improved to realize sustainable institutions

\section{Research Methodology}

This research was taken in Karangsong, Indramayu Regency. The Ministry of Environment and Forestry. contend that Karangsong become mangrove center in West Java in 2015 [10]. Descriptive analysis method used in this paper. The study describing: a) how the impact of one-sided claiming of one of the stakeholders and b) also impact the transfer of ownership of mangrove conservation area.

\section{The Result And Discussion}

Mangrove in Karangsong was conversion into fishpond and caused problem of abrasion since 1962 and in 2008 had erosion of the coast along 48.57 [11]. Then the local community group carried out the greening movement with the help of the local government. They began cultivate mangrove as a way to reduce abrasion. Furthermore, several stakeholders were involved in the rehabilitation activities. The stakeholders involved are Large River Basin Organizations (BBWS) CimanukCisanggarung, Fisheries and Marine Office (DISKANLA) Regency of Indramayu, Corporate Social Responsibility Pertamina Balongan RU VI, KEHATI foundation, Mangrove Forest Management (BPHM) Region 1 Bali, Dekon Ministry of Marine Affairs and Fisheries, Corporate Social Responsibility PT. Traktor Nusantara Jakarta, Mangrove for the Future Indonesia (MFF), and Ministry of Marine Affairs and Fisheries.

From several stakeholders involved in the mangrove planting, one of the stakeholders who claimed the success of mangrove rehabilitation in Karangsong is Pertamina's Corporate Social Responsibility Balongan RU-VI. Pertamina Balongan's CSR stated that the success of the coastal reforestation program in Karangsong was a manifestation of harmonization that took into account environmental, social and economic impacts. This was done by encouraging the development of the Karangsong coastal area in Indramayu as a center of edupark-based mangrove excellence. So that later developed into ecotourism. However, with the unilateral claim from Pertamina, according to the explanation of Pantai Lestari group stated that Pertamina did contribute a lot, but the number of trees planted was only 15,000 mangrove seeds. Furthermore, the support from Pertamina to mangrove forest in Karangsong includes promoting Karangsong to various media so that it can be widely known as a form of success in mangrove rehabilitation in overcoming abrasion problems. In fact, Pertamina Balongan's own claim does not negatively affect both Pantai Lestari group itself and Karangsong. It's just that there are several other stakeholders who did not accept because Pertamina Balongan just entered the rehabilitation program in 2010. While the mangrove rehabilitation program itself started in 2007.

In addition, the Indramayu regional government through the Indramayu Regent Regulation No.14 of 2017 Article 4 Paragraph 1 also states that the management of tourism that owned by government, must be managed by a CV (commanditaire vennootschap), PT or cooperative with legal entity. Based on that regent's regulation, the Head of Indramayu Regency Culture and Tourism Office issued Decree No. 556.31 / 226-Disbudpar / 2017 concerning to the establishment of Karangsong coastal tourism managers. The letter stipulates that the management of the Karangsong Beach tourism object including the management of Mangrove Forest is cooperated with a private $\mathrm{CV}$. Then, Pantai Lestari group confirmed that the mangrove forest area belongs to the 
government. Meanwhile, Pantai Lestari group is given the right to manage the mangrove forest area. The management provided to Pantai Lestari group is only given management rights for five years.

Based on the Decree of the Culture and Tourism Office of Indramayu with the confirmation from Pantai Lestari group, there were two managers in the Karangsong mangrove forest area. This poses a threat to the sustainability of mangrove forest conservation areas. The entry of the private sector in Karangsong raises a new polemic, because in reality the Karangsong Beach area itself already has three groups that have their respective regions and still not integrated with each other. First, the Pantai Lestari group that manages the mangrove forest area. Second, Karangtaruna which manages the portal and entrance ticket. And third, the Pantai Mutiara Hijau group that manages the Karangsong beach area. For now, the private CV assigned under the Decree of the Culture and Tourism Office of Indramayu Regency only manages parking area in the Karangsong Beach Area.

There are at least three problems that exist in Karangsong mangrove forest as a result of the development mangrove rehabilitation into mangrove ecotourism. First, the function of mangrove forests to become ecotourism raises its own problems related to its function as a conservation area. Second, the transfer of land ownership in the mangrove forest area to the Indramayu regional government also has an impact on the Pantai Lestari group in managing mangrove forests. That impact just extending other conflict between local group in Karangsong area. Other than that, with the issuance of the Indramayu regent Regulation No.14 of 2017 and the Decree of the Culture and Tourism Office also indirectly eliminated the role of Pantai Lestari Beach group in managing mangrove forests. The removal of this role is feared to threaten the sustainability of mangrove forest conservation areas. The third is that the $\mathrm{CV}$ from the private sector is appointed to manage the mangrove ecotourism area which can lead to a shift in conservation orientation towards the economy orientation. Because the private sector only wants profit, while local groups that plant mangroves and rehabilitate mangroves aim to protect the coastal areas. Protecting coastal area from the impact of waves that can cause abrasion. In addition, a unilateral clause from the state-owned oil company also hurt several stakeholders who were involved from the beginning of the rehabilitation mangroves in Karangsong. Although it does not create significant conflicts between others stakeholders.

\section{The Problem}

Problems between stakeholders related to the management of the Karangsong coastal area will ultimately have an impact on the sustainability of mangrove forests. The conflict was caused by the lack of synergy between groups that manage the Karangsong coastal area. In addition, the Karangsong village government itself has seen no attempt to unite several local group management in Karangsong coastal area. Sustainability of Karangsong mangrove forest, ultimately, depends on stakeholders and their management. Policies made by local governments are also considered to be impartial to the community and are considered detrimental to local groups in Karangsong

Conclusion and Recomendation

Mangrove rehabilitation can provide benefits to local communities, not only from the ecological side but from the social and economic aspects. The development of mangrove forests into ecotourism has caused several problems. Among them are decisions from the Indramayu regional government regarding the status of Karangsong Beach and include mangrove forests. The role of stakeholders greatly influences the management and sustainability of mangrove forests in Karangsong. Therefore, a unilateral claim from one of the stakeholders will trigger a conflict that can affect the sustainability of mangrove forests. Integration and regulation are needed which regulates several groups that manage the Karangsong Beach area to minimize conflict between groups. To achieve the sustainability of the mangrove conservation area is needed regulation that not only benefits the government but also must involve the community in making the policy. In addition to the importance of sustainability, mangrove conservation is the main thing in conservation efforts.

\section{References}

1. Alongi, Daniel. M. Carbon sequestration in mangrove forests. Journal Carbon Management, 3(3), 313-322. (2012). https://doi.org/https://doi.org/10.4155/cmt.12.20

2. Mahi, Ali Kabul. Pengembangan Wilayah Teori dan Aplikasi. Kencana: Jakarta. (2016).

3. Duncan, CA. Mangrove Forest Ecosystem Services: Biodiversity Drivers, Rehabilittaion and Resilience to Climate Change. Doctoral Thesis. University College London. (2017).

4. Andradi-brown, Dominic. A., Howe, Caroline., Mace, Georgina. M., \& Knight, Andrew. T. Do mangrove forest restoration or rehabilitation activities return biodiversity to pre-impact levels? Environmental Evidance Journal, 2(20), 1-8. (2013).

5. Prayudha, Egar Dwi. Sulardiono, Bambang. Hendrarto, Boedi. Strategi Kelompok Pantai Lestari dalam Pengembangan Kegiatan Rehabilitasi Mangrove di Desa Karangsong Kabupaten Indramayu. Diponegoro Journal of Maquares. Management of Aquatic Resources. Vol 3. No. 3. Hal 80-87. (2014).

6. Wahyuni, Sri. Sulardiono, Bambang. Hendrarto, Boedi. Strategi Pengembangan Ekowisata Mangrove Wonorejo Kecamatan Rungkut Surabaya. Diponegoro Journal of Maquares. Management of Aquatic Resources. Vo. 4. No. 4. Hal 66-70. (2015).

7. Kustanti, A., Nugroho, B., Kusmana, C., Darusman, D., Nurrochmat, D., Krott, M., \& Schusser, C. Actor , Interest and Conflict in Sustainable Mangrove Forest Management - A Case from Indonesia. International Journal of Marine Science, 4(16), 150 159. https://doi.org/10.5376/ijms.2014.04.0016. 
8. Kustanti, A., Nugroho, B., Nurrochmat, D. R., \& Okimoto, Y. Evolusi Hak Kepemilikan dalam Pengelolaan Ekosistem Hutan Mangrove di Lampung Mangrove Center. Risalah Kebijakan Pertanian Dan Lingkungan, 1(3), 143-158. (2014).

9. Gunawan, Ali. Hidayat, Aceng, Anggraini, Eva. Institutional Analysis of Mangrove Rehabilitation in Karangsong Indramayu West Java. Solidaty. Jurnal Sosiologi Pedesaan. Departement of Communication and Community Development. Faculty of Human Ecology IPB - Associated with Indonesian Sociological Association.) Vol. 6 No. 1 (2018).

10. Sodikin, S., Sitorus, S. R. P., Prasetyo, L. B., \&
Kusmana, C. Spatial Analysis of Land Adjustment as a Rehabilitation Base of Mangrove in Indramayu Regency. In 2nd Geoplanning-International Conference on Geomatics and Planning (pp. 1-9). IOP Conf. Series: Earth and Environmental Science 123. (2018).

11. BPLHD (Badan Lingkungan Hidup Daerah) Jawa Barat, 2008 available at: http://www.bplhdjabar.go.id/index.php/layanan/dok umen/kegiatan/slhd/tahun-2008 diakses tanggal 30 januari 2017 jam 15:34. 